\title{
Analisis Kelelahan Pekerja Pengolah Kerupuk di Kota Bangun Kalimantan Timur
}

\author{
Etwin Fibrianie $^{1^{*}}$, M. Zainul R ${ }^{2}$, Dwi Cahyadi ${ }^{3}$ \\ ${ }^{1,2,3}$ Politeknik Negeri Samarinda \\ *Email:etwin@polnes.ac.id
}

\begin{abstract}
Ergonomic work posture, can lead to fatigue and may lead to the occurrence of accidents and occupational diseases. This research was intended to measure whether the working conditions of workers processing fish crackers could pose potential fatigue, What the dimensions of the machine processing crackers influential significantly to worker fatigue is, and whether the work station layout affects the level of fatigue of the workers. The model design of the experimental design used was treatment by subject design. Musculoskeletal complaints data collection and the level of fatigue is done with a questionnaire with 15 questions to item 20 respondents. From the results of the processing in the can that the environmental conditions do not provide for worker conditions influence in working to cultivate crackers (room temperature $+/-260 \mathrm{c}$ ). There are complaints of musculoskeletal operator in the processing activity is carried out by analysis where crackers test paired $t$-statistics with the results $t$-Stat $<t$ test $(-9,51<2.144)$. From the statistics, test results obtained there was significant influence between the layout of work station with fatigue of workers $0.00033<0.05$. In addition, there was no significant influence between the ergonomics of the dimensions of the machine with the fatigue of workers, $0107>0.05$.
\end{abstract}

Keywords: Musculoskelethal, fatigue, ergonomic, physiological

\begin{abstract}
Abstrak
Sikap kerja yang tidak ergonomis, dapat menimbulkan kelelahan serta dapat mengakibatkan terjadinya kecelakaan dan penyakit akibat kerja. Penelitian ini ditujukan untuk mengukur apakah kondisi kerja pekerja pengolah kerupuk ikan dapat menimbulkan potensi kelelahan, apakah dimensi mesin pengolah kerupuk berpengaruh signifikan terhadap kelelahan pekerja, apakah layout stasiun kerja mempengaruhi tingkat kelelehan pekerja. Model rancangan yang digunakan adalah rancangan eksperimental treatment by subject design. Pengumpulan data keluhan muskuloskeletal dan tingkat kelelahan dilakukan dengan teknik kuesioner dengan 20 item pertanyaan kepada 15 responden. Dari hasil pengolahan di dapat bahwa Kondisi lingkungan tidak memberikan pengaruh bagi kondisi pekerja dalam bekerja mengolah kerupuk (Suhu ruangan $+/-26{ }^{\circ} \mathrm{C}$ ). Terdapat keluhan musculoskeletal pada operator dalam kegiatan pengolahan kerupuk dimana analisa dilakukan dengan uji t-paired statistic dengan hasil t-Stat $<\mathrm{t}$ hitung $(-9,51<$ 2.144). Dari hasil uji statistic, didapat ada pengaruh signifikan antara layout stasiun kerja dengan kelelahan pekerja, $0.00033<0.05$. Selain itu, tidak terdapat pengaruh yang signifikan antara ergonomi dimensi mesin dengan kelelahan pekerja, $0.107>0.05$.
\end{abstract}

Kata kunci: Muskuloskeletal, kelelahan, fisiologis, ergonomis 


\section{PENDAHULUAN}

Tren perkembangan penelitian dari keilmuan Teknik Industri saat ini tidak hanya terfokus pada sektor manufaktur, pengembangan desain produk, ataupun sistem rekayasa. Hal ini dapat dilihat pada tren perkembangan penelitian dari salah satu lingkup keilmuan Teknik Industri, yakni Ergonomi dan Biomekanika, yang saat ini sebanyak berkontribusi pada bidang kedokteran khususnya yang berkaitan dengan berkurangnya kemampuan fisik dalam aktifitas sehari-hari atau yang lebih dikenal dengan istilah ADLs (Activities of Daily Living) [8].

Dengan biomekanika dapat dianalisa apakah sikap atau posisi kerja seseorang dapat memberikan resiko cidera. Sehingga diharapkan resiko cidera pada seseorang dapat dicegah [3]. Biomekanika kerja adalah studi mengenai interaksi pekerja dengan peralatan, mesin dan material sehingga dapat meningkatkan performansi pekerja dan di sisi lain dapat meminimalkan resiko cedera kerja [2].

Biomekanika merupakan ilmu pengetahuan yang terdiri dari berbagai macam ilmu yang merupakan kombinasi dari ilmu fisika (khususnya mekanika) dan teknik, dengan dasar dari biologi dan juga pengetahuan lingkungan kerja. Analisis biomekanika ini dilakukan untuk mengetahui besarnya gaya tekan pada lempeng tulang belakang bagian bawah tepatnya lumbar nomor lima dengan sacrum nomor satu (L5/S1)[13].

Pekerja sering mempunyai keluhankeluhan pada tubuh mereka. dan yang paling sering dikeluhkan pekerja yaitu bagian pinggang. FC (Force Compression) gaya tekan yang diakibatkan dari pekerjaan ini paling besar berada pada Lumbar 5 Sacrum 1 (L5/S1) yaitu ruas tulang belakang. Hal ini dikarenakan aktivitas pekerja dilakukan dengan posisi membungkuk dan pada saat membungkuk itu pekerja harus mengangkat [2].

Beberapa faktor yang berpengaruh dalam pemindahan material sebagai berikut [7] :
1) Berat beban yang harus diangkat dan perbandingan dengan berat badan operator.

2) Jarak horizontal dari beban relatif terhadap operator.

3) Ukuran beban yang harus diangkat (beban yang berat akan memiliki pusat masa (center of gravity) yang letaknya jauh dari badan operator, hal tersebut juga akan menghalangi pandangan.

4) Ketinggian beban yang harus diangkat dan jarak perpindahan beban. Mengangkat beban dari permukaan lantai akan relatif lebih sulit dari pada mengangkat beban dari ketinggian pada permukaan pingang.

5) Beban puntir (twisting load) pada badan operator selama aktivitas akngkat beban.

6) Prediksi terhadap berat bebean yang aakan diangkat. Hal ini adalah untuk mengantisipasi beban yang lebih berat dari yang diperkirakan.

7) Stabilitas beban yang diangkat

8) Kemudahan untuk dijangkau oleh pekerja

9) Kondisi kerja yang meliputi pencahayaan,temperatur, kebisingan dan kelicianan lantai

10) Berbagai rintangan yang menghalangi dan keterbatasan postur yang berada pada suatu tempat kerja.

11) Frekuensi angkat.

12) Metode angkat yang benar (tidak boleh mengangkat beban tiba-tiba)

13) Diangkatnya beban dalam periode tertentu. Hal ini adalah sama dengan membawa beban pada jarak tertentu akan membrikan tambahan beban pada ruas-ruas tulang belakang.

Sikap kerja yang kurang fisiologis, juga dapat menimbulkan kelelahan dan berbagai gangguan pada sistem otot skeletal serta memerlukan energi yang lebih besar. Kondisi seperti ini, dapat mengakibatkan terjadinya kecelakaan dan penyakit akibat kerja. Pengukuran kelelahan secara subjektif, diketahui bahwa dari 10 penjahit di wilayah 
Ketapang Cipondoh Tangerang, 70\% dari responden mengalami kelelahan kerja [11]. Perbaikan shift kerja pekerja housekeeping berbasis ergonomi dapat menurunkan keluhan musculoskeletal pada pekerja housekeeping sebesar 36,31\% [1].

Penggunaan tenaga manusia sebagai pekerja sangatlah dominan terutama kegiatan penanganan material secara manual (Manual Material Handling, MMH). Aktivitas Manual Material Handling teridentifikasi beresiko tinggi sebagai penyebab utama timbulnya cedera pada otot rangka (musculoskeletal disorders)[12]

Aktivitas $\mathrm{MMH}$ meliputi mengangkat, menurunkan, menarik, mendorong, dan membawa merupakan sumber komplain bagi para pekerja, karena terjadi banyak keluhan akibat pekerjaan tersebut. Cara paling efektif untuk mengurangi dan mencegah resiko kerja tersebut adalah dengan engineering control selain mengubah pekerjaan menjadi otomatis atau menguranginya dengan desain ergonomis. Parameter yang menjadi pertimbangan dalam pekerjaan $\mathrm{MMH}$ adalah frekuensi pekerjaan, jarak angkat dan berat beban [10].

Setelah menggunakan mesin dan melayout ulang stasiun kerjanya, operator UD. Sanda Kerupuk Ikan Sungai ini masih terdapat keluhan beban berat pengangkatan hasil penghalusan ikan menuju stasiun pengadonan (pencampuran bahan-bahan). Diduga bahwa ada factor yang mempengaruhi terjadinya kelelahan dalam serangkaian proses produksinya. Atas dasar tersebut, penelitian ini akan membahas tentang factor pengaruh kelelahan operator dalam proses produksinya menggunakan mesin pengolah (potong dan giling) [4].

UD. Sanda Kerupuk Ikan awalnya mengolah kerupuk dengan proses manual, kecuali untuk proses penghalusan ikan. Penelitian sebelumnya telah membuat mesin pengolah kerupuk yang semiotomatis, yakni proses giling dan potong menggunakan mesin dan proses mengadon tetap manual. Mesin yang dibuat telah di desain sesuai dengan antropometri operator, diharapkan bahwa mesin dapat mengurangi kelelahan operator saat memotong kerupuk dan menggiling kerupuk [5].

Kelelahan yang minimal, kenyamanan ketika bekerja merupakan factor utama dalam peningkatan hasil yang signifikan. Oleh karena itu diperlukan adanya suatu analisa pengaruh kondisi kerja pekerja pengolahan kerupuk ikan terhadap aspek ergonomic, biomekanika, dan fisologi. Tujuan penelitian ini adalah membuktikan bahwa dimensi mesin berpengaruh terhdap kelelahan ketika operator bekerja juga membuktikan apakah layout. Stasiun kerja dengan menggunakan mesin pengolah berpengaruh pada tingkat kelelahan operator di saat bekerja.

\section{METODOLOGI}

Rancangan eksperimental penelitian ini adalah rancangan sama subjek, karena keterbatasan jumlah populasi. Focus Group Discussion (FGD) merupakan teknik dalam mengumpulkan data kualitatif, namun dapat juga digunakan sebagai salah satu metode edukasi [9]. Melalui pendekatan data kualitatif, kuisioner yang dibagikan kepada pekerja, dimana item pertanyaan berisi tentang kelelahan dan keluhan muskoleskeletal pekerja.

\section{Populasi dan Sampel}

Populasi target dalam penelitian ini adalah semua pekerja pengolah kerupuk dan beberapa diantaranya adalah orang dewasa yang memiliki karakter kerja yang hampir sama dan ciri menyerupai operator yang ada. Sampel yang di gunakan sebanyak 15 orang.

\section{Instrumen Penelitian}

Keluhan muskuloskletal pada subjek penelitian diukur dengan kuesioner Nordic Body Map empat skala likert. Kelelahan diukur menggunakan kuesioner 20 item pertanyaan. Pengolahan data menggunakan analisis regresi menggunakan data analysis tool pack Ms. Excel 2007. Yang akan dianalisis adalah : 
1. Ada atau tidaknya pengaruh dimensi mesin pengolah (penggiling dan pemotong) kerupuk juga layout (tata letak) stasiun kerja saat ini dengan tingkat kelelahan operator. Pengujian yang dilakukan adalah dengan Data berdistribusi normal kemudian diuji dengan t-paired dengan taraf kemaknaan 5\% $(\alpha=0,05)$.

2. Ada atau tidaknya pengaruh layout (tata letak) stasiun kerja saat ini dengan tingkat kelelahan operator. Pengujian yang dilakukan adalah dengan data berdistribusi normal kemudian diuji dengan t-paired dengan taraf kemaknaan 5\% $(\alpha=0,05)$.

3. Apakah terjadi keluhan musculoskeletal atau tidak kondisi kerja saat sebelum dan setelah melakukan kegiatan pengolahan kerupuk. Data berdistribusi normal kemudian diuji dengan t-paired dengan taraf kemaknaan 5\% $(\alpha=0,05)$.

\section{HASIL DAN PEMBAHASAN}

Penelitian ini melibatkan 15 orang operator pengolah kerupuk sebagai subjek. Subjek yang terlibat berusia 21 tahun hingga 40 tahun dengan rata - rata usia 30,4 tahun. Kemampuan fisik akan semakin menurun seiring bertambahnya usia [6].

\section{Kondisi Lingkungan}

- Suhu yang nyaman untuk daerah tropis adalah antara $22^{\circ} \mathrm{C}$ hingga $28^{\circ} \mathrm{C}$ dengan kelembaban relative antara $70 \%$ hingga $80 \%$. Hal tersebut menunjukkan suhu di lingkungan kerja yang ada adalah suhu yang nyaman untuk bekerja. Suhu di ruang kerja pengolahan kerupuk relative nyaman, yakni $+/-26^{0} \mathrm{C}$.

- Kebisingan di lingkungan kerja juga masih berada dalam batas yang ditetapkan oleh Peraturan Menteri Negara Lingkungan Hidup No: Kep48/MENLH/11/1996 yakni 85dB [1]. Tingkat kebisingan di lingkungan industri jasa tidak lebih dari $72 \mathrm{~dB}$.

- Pencahayaan di tempat kerja pengolahan kerupuk berasal dari pencahayaan alami (sinar matahari yang masuk melalui jendela kaca dan pintu) dan buatan (lampu), dimana pencahayaan yang disarankan adalah berada di range 100 300 lux. Di lapangan pencahayaan terukur 256 lux)

- Penghawaan di stasiun kerja pengolahan kerupuk adalah baik. Adanya jendela dan pintu juga adanya exhaust fan menyebabkan sirkulasi udara menjadi baik.

Dari uraian diatas dapat disimpulkan bahwa lingkungan kerja tidak berpengaruh terhadap faktor fisiologi operator.

\section{Kelelahan Musculoskeletal}

Karena masih terdapat proses mengangkat dan berjalan dari mesin giling ikan menuju stasiun adonan yang berada melantai, maka dilakukan analisa terhadap keluhan otot tangan dan musculoskeletal dengan penyebaran kuisioner dan wawancara terhadap operator. Analisa dilakukan dengan uji t-paired statistic dengan hasil t-Stat $<\mathrm{t}$ hitung $(-9,51<2.144)$ yang berarti terdapat keluhan musculoskeletal pekerja saat bekerja membuat kerupuk terhadap kondisi normal.

Tabel 1. Uji statistic terhadap musculoskeletal

t-Test: Paired Two Sample for Means

\begin{tabular}{|c|c|c|}
\hline & Sebelum & Sesudah \\
\hline Mean & 3.36 & 4.36 \\
\hline Variance & 0.155428571 & 0.035428571 \\
\hline Observations & 15 & 15 \\
\hline $\begin{array}{l}\text { Pearson Correlation } \\
\text { Hypothesized Mean }\end{array}$ & 0.169411303 & \\
\hline Difference & 0 & \\
\hline $\mathrm{df}$ & 14 & \\
\hline t Stat & -9.514054939 & \\
\hline $\mathrm{P}(\mathrm{T}<=\mathrm{t})$ one-tail & $8.62567 \mathrm{E}-08$ & \\
\hline t Critical one-tail & 1.761310115 & \\
\hline $\mathrm{P}(\mathrm{T}<=\mathrm{t})$ two-tail & $1.72513 \mathrm{E}-07$ & \\
\hline t Critical two-tail & 2.144786681 & \\
\hline
\end{tabular}

\section{Layout stasiun kerja}

Setelah pengujian terhadap ada tidaknya keluhan musculoskeletal terhadap posisi kerja saat pengolahan, maka dilakukan uji lanjutan terhadap layout kerja operator yakni pada bagian adonan kerupuk. Apakah layout berpengaruh signifikan terhadap kelelahan pekerja. Adapun hasil uji statistiknya adalah sebagai berikut: 
Tabel 2. Uji statistic pengaruh layout stasiun kerja terhadap kelelahan

\begin{tabular}{|c|c|c|c|c|c|}
\hline ANOVA & & & & & \\
\hline & $d f$ & $S S$ & $M S$ & $F$ & $\operatorname{Sig} F^{-}$ \\
\hline Regression & 1 & 139.52 & 139.52 & 23.31 & 0.0003 \\
\hline Residual & 13 & 77.81 & 5.99 & & \\
\hline \multirow[t]{2}{*}{ Total } & 14 & 217.33 & & & \\
\hline & Coef & $\begin{array}{c}\text { Standard } \\
\text { Error }\end{array}$ & $t$ Stat & $\begin{array}{c}P- \\
\text { value }\end{array}$ & $\begin{array}{c}\text { Lower } \\
95 \%\end{array}$ \\
\hline Intercept & $5.6 \overline{1}$ & 12.43 & -0.45 & 0.66 & 32.464 \\
\hline Layout & 0.89 & 0.19 & 4.83 & 0.0003 & 0.496 \\
\hline
\end{tabular}

P-value $<0.05$ yakni $0.00033<0.05$ sehingga Ho ditolak yang berarti layout stasiun kerja berpengaruh terhadap kelelahan pekerja dalam bekerja.

\section{Dimensi Mesin}

Adapun dimeNsi mesin seperti tampak pada gambar :
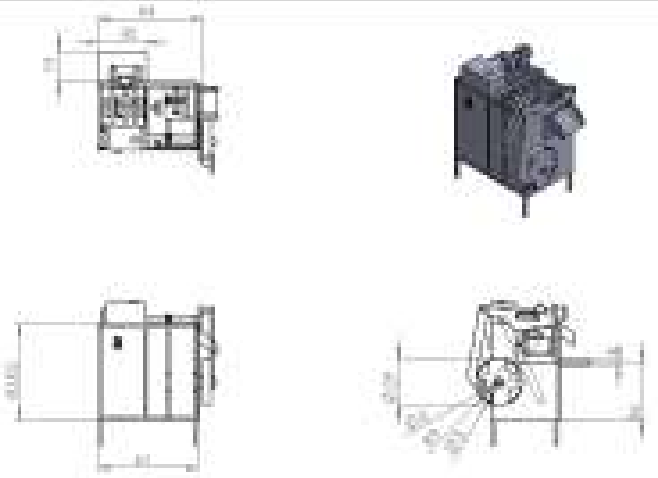

Gambar 1. Mesin pengolah kerupuk

Dimensi mesin pengolah kerupuk telah sesuai dengan prinsip ergonomic dan sesuai dengan antropometri tubuh pekerja. Hal tersebut pun sesuai uji statistic $(\mathrm{p}>0.05)$ yang berarti tidak pengaruh dimensi tubuh terhadap kelelahan pekerja.

Tabel 3. Uji statistic pengaruh dimensi mesin terhadap kelelahan

ANOVA

\begin{tabular}{lccccc}
\hline & $d f$ & $S S$ & $M S$ & $F$ & Sig $F$ \\
\hline Regression & 1 & 21.66 & 21.66 & 2.99 & 0.107 \\
Residual & 13 & 94.07 & 7.24 & & \\
Total & 14 & 115.73 & & & \\
& & & & & \\
\hline
\end{tabular}

P-value $<0.05$ yakni $0.107>0.05$ sehingga Ho diterima yang berarti dimensi mesin berpengaruh terhadap kelelahan pekerja dalam bekerja.

\section{KESIMPULAN}

Berdasarkan dari hasil analisis dan pembahasan yang sudah dilakukan, maka dapat disimpulkan bahwa:

1. Kondisi lingkungan tidak memberikan pengaruh bagi kondisi pekerja dalam bekerja mengolah kerupuk. Suhu ruangan $+/-26{ }^{0} \mathrm{C}$, Kebisingan di lingkungan kerja juga masih berada dalam batas normal $+/$ $72 \mathrm{~dB}$ (bats maksimal kebisingan $85 \mathrm{~dB}$ ), pencayaan terukur 256 lux.

2. Analisa terhadap kelelahan musculoskeletal dilakukan dengan uji tpaired statistic dengan hasil $\mathrm{t}-\mathrm{Stat}<\mathrm{t}$ hitung $(-9,51<2.144)$ yang berarti terdapat keluhan musculoskeletal pekerja saat bekerja membuat kerupuk terhadap kondisi normal.

3. Dimensi mesin pengolah kerupuk telah sesuai dengan prinsip ergonomic dan sesuai dengan antropometri tubuh pekerja. Hal tersebut sesuai uji statistic $(\mathrm{p}>0.05)$ yang berarti tidak pengaruh dimensi tubuh terhadap kelelahan pekerja.

4. Layout stasiun kerja perlu di benahi, karena dari kuisioner yang di analisis merekomendasikan adanya perbaikan (redisgn tempat kerja). Hal tersebut sesuai uji statistic $(\mathrm{p}>0.05)$ yang berarti ada pengaruh layout stasiun kerja terhadap kelelahan pekerja.

\section{SARAN}

Perlunya redesain stasiun kerja, yakni perbaikan pada stasiun pencampuran adonan agar didekatkan pada stasiun penggilingan dan 
pemotongan. Hal tersebut di perkirakan akan dapat mereduksi waktu pindah antar stasiun kerja, dan dapat mengurangi tingkat kelelahan serta keluhan musculoskeletal pada pekerja.

\section{DAFTAR PUSTAKA}

[1] Angelin Tabita, Nyoman Adiputra , I Nyoman Sutarja, "Pengaturan Organisasi Kerja Housekeeping dengan Pendekatan Ergonomi dapat Menurunkan Keluhan Muskuloskeletal, Kelelahan, dan mempercepat Waktu Kerja”, Jurnal Ergonomi Indonesia, vol.3 no.1, hal. 3948, Juni 2017.

[2] Dinar Prasetyawan, Etika Muslimah, Suranto, "Analisis Resiko Angkat Beban Berdasarkan Biomekanika Dan Fisiologi”, Tugas Akhir. Jurusan Teknik Industri. Universitas Muhammadiyah Surakarta, 2014.

[3] Eko Nurmianto, Ergonomi : Konsep Dasar dan Aplikasinya. Edisi Kedua Guna Widya, Surabaya, Indonesia, 2008.

[4] Etwin Fibrianie, Dwi Cahyadi, dan Andi Farid, Rancang Bangun Mesin Pengolah Kerupuk Ikan Sungai Guna Meminimalkan Waktu Produksi Dan Mengoptimalkan Inventory pada UD. Sanda Kota Bangun Kalimantan Timur. Laporan Penelitian Hibah Bersaing, Politeknik Negeri Samarinda, 2017.

[5] Etwin Fibrianie, Dwi Cahyadi, dan Andi Farid, "Rancang Bangun Mesin Penggiling Dan Potong Kerupuk Ikan Dengan Menggunakan Gear box", Jurnal Riset Teknologi Industri. Kementerian Perindustrian. Vol. 12 No. 1, 2018.

[6] Grandjean, E, Fitting the Task tothe Man. A Texbook of Occupational Ergonomic. New York: Taylor and Francis.

[7] I Wayan Sukania, "Analisa Ergonomi Kegiatan Mengangkat Beban Studi Kasus Mengangkat Galon Air Ke Atas Dispenser",http://repository.untar.ac.id/i d/eprint/10, 2017.
[8] Irma Nur Afiah, "Pendekatan Biomekanika Pada Analisa Pengaruh Usia Terhadap Karakteristik Gerak Berjalan Untuk Individu Usia Lanjut”, Jurnal PASTI. Volume XI No. 2, 123 129. 2017.

[9] Marianti Avi, Susanti, Much Ilham, Aji Wibowo, "Perbandingan Metode CBIA dan FGD dalam peningkatan pengetahuan dan ketepatan Caregiver dalam upaya swamedikasi demam pada Anak", Jurnal Pharmaceutical Sciences \& Research (PSR). August 2015 . Vol. 2 No.

psr.ui.ac.id/index.php/journal/article/vie w/3336

[10] Muslimah, Etika, "Analisis Terhadap Load Constant (LC) Dalam Revised Niosh Lifting Equation", Laporan Tesis. Universtas Gajah Mada. Yogyakarta, 2008.

[11] Umyati, "Faktor-faktor yang Berhubungan dengan Kelelahan Kerja pada Pekerja Penjahit Sektor Usaha Informal di Wilayah Ketapang Cipondoh Tangerang Tahun 2009”, Laporan Skripsi, Universitas Islam Negeri Syarif Hidayatullah Jakarta Fakultas Kedokteran Dan Ilmu Kesehatan Program Studi Kesehatan Masyarakat, 2010.

[12] Rapiah Sarfa Marasabessy, "Penentuan Maximum Acceptable Weihght Limit (Mawl) dengan menggunakan Pendekatan Fisiologi" Jurnal ARIKA, Vol. 06, No. 1, Pebruari 2012.

[13] Yanti Helianty, Regi Hermawan, Caecilia Sri Wahyuning, "Perbaikan Stasiun Kerja Serut Berdasarkan Aspek Antropometri Dan Biomekanika. Seminar Nasional" Makalah Seminar ITENAS, dalam http://lib.itenas.ac.id/kti/ wp-content/uploads/2014/03/Makalahseminar-_2009_-OK.pdf, 2009. 